KRZYSZTOF SALA

Uniwersytet Pedagogiczny w Krakowie, Polska - Pedagogical University of Cracow, Poland

\title{
Energetyka słoneczna jako czynnik rozwoju regionów i gmin w Polsce
}

\section{Solar Power as a Factor in the Development of Regions and Communes in Poland}

Streszczenie: Odnawialne źródła energii (OZE) leżą w gestii zainteresowań wielu naukowców na całym świecie. Przesłankami do prowadzenia badań naukowych nad OZE są:

- globalny wzrost zapotrzebowania na energię,

- perspektywa wyczerpania się zapasów tradycyjnych paliw kopalnych.

W dalszym ciągu poszukuje się najbardziej ekologicznych i ekonomicznych rozwiązań w energetyce. Pośród wielu rodzajów alternatywnych rodzajów energii, które można praktycznie wykorzystywać, warto zwrócić uwagę na energię słoneczną. Celem publikacji było przedstawienie zastosowanie energii słonecznej, szczególnie fotowoltaiki, jako elementu pobudzającego rozwój gospodarczy regionów i gmin w Polsce. W artykule zaprezentowano uwarunkowania i początki rozwoju energetyki słonecznej na świecie. Ukazano zarówno zalety, jak i wady energetyki słonecznej oraz wskazano liderów światowych w wykorzystywaniu energii słońca. Szczególną uwagę poświęcono stosowaniu energetyki słonecznej w Polsce. Opisano warunki i poziom wykorzystywania energii słońca na terenie Polski. Wskazano na konkretne korzyści dla gospodarki wynikające z jej przetwarzania. Publikacja powstała na podstawie ogólnodostępnych danych statystycznych, a także literatury zwartej i źródeł internetowych. Metodą badawczą, jaką zastosowano w artykule, była krytyka piśmiennicza literatury obejmującej poruszaną tematykę. Podejście badawcze uwzględniało dane ilościowe i jakościowe dotyczące bazy noclegowej i jej wpływu na gospodarkę regionów. Narzędzie badawcze stanowiła analiza danych zastanych. Tezą, jaką postawiono w publikacji, było założenie, że energetyka słoneczna w istotny sposób wpływa na sytuację gospodarczą regionów. Wyniki badań pozytywnie zweryfikowały postawioną tezę.

Abstract: Renewable energy sources (RES) are the responsibility of many scientists around the world. The prerequisites for researching RES are:

- global demand growth,

- perspectives of exhaustion of traditional fossil fuel stocks.

We are still looking for the most ecological and economic solutions in the power industry. Among the many types of alternative energy that can be practically used, it is worth to pay attention to the use of solar energy.The purpose of the publication was to present the use of solar energy, mainly photovoltaic, as an element stimulating the economic development of regions and communes in Poland. The article presents the conditions and origins of solar energy development in the world. Both the advantages and 
disadvantages of solar energy have been highlighted and the world leaders in the use of solar energy have been mentioned. Particular attention has been paid to the use of solar energy in Poland. The conditions and level of sun energy utilisation in Poland are described. Indicated were the specific benefits to the economy resulting from its processing. The publication was based on publicly available statistics, as well as on compact literature and online sources. The research method used in the article was the literary critique of literature covering the subject matter. The research approach included quantitative and qualitative data on accommodation and its impact on the economies of the regions. The research tool was an analysis of the data in question. The thesis set out in the publication was the assumption that solar energy has a significant impact on the economic situation of the regions. The results of the study positively verified the thesis.

Słowa kluczowe: ekologia; energetyka słoneczna; odnawialne źródła energii; regiony; rozwój

Keywords: development; ecology; regions; renewable energy sources; solar energy

Otrzymano: 10 września 2017

Received: 10 September 2017

Zaakceptowano: 9 czerwca 2018

Accepted: 9 June 2018

\section{Sugerowana cytacja/Suggested citation:}

Sala,K.(2018).EnergetykasłonecznajakoczynnikrozwojuregionówigminwPolsce.Przedsiębiorczość - Edukacja [Entrepreneurship - Education], 14, 125-136. DOI: 10.24917/20833296.14.9

\section{Wstęp}

Wykorzystywanie odnawialnych źródeł energii (OZE) wpisuje się w światowy trend poszukiwania nowych, ekologicznych źródeł energii i ich dywersyfikacji. Ciągły wzrost zapotrzebowania na energię na świecie oraz perspektywa wyczerpania się zapasów paliw kopalnych znacznie zwiększają zainteresowanie odnawialnymi źródłami energii i metodami ich wykorzystywania. Spośród wielu rodzajów alternatywnych rodzajów energii warto wziąć pod uwagę energię słoneczną.

Celem publikacji było przedstawienie wykorzystania energii słonecznej, a w szczególności ogniw fotowoltaicznych, jako elementu pobudzającego rozwój gospodarczy regionów w Polsce. Artykuł prezentuje uwarunkowania i zalążki rozwoju energetyki słonecznej na świecie. Ukazuje korzyści i mankamenty w stosowaniu energetyki słonecznej, pokazuje również światowych liderów w wykorzystywaniu tego rodzaju nośnika energii.

Szczególną uwagę poświęcono stosowaniu energetyki słonecznej w Polsce. Pokazano sytuację energetyki słonecznej w Polsce. Wskazano na konkretne korzyści dla gospodarki wynikające z jej przetwarzania.

Publikacja powstała na podstawie ogólnodostępnych danych statystycznych, a także literatury zwartej i źródeł internetowych. Metodą badawczą, jaką zastosowano w artykule, była krytyka piśmiennicza literatury obejmującej poruszaną tematykę. Narzędzie badawcze stanowiła analiza danych zastanych.

Tezą, jaką postawiono w publikacji, jest założenie, że energetyka słoneczna w znaczący sposób wpływa na sytuację gospodarczą regionów. Wyniki badań pozytywnie zweryfikowały postawioną tezę. 
Uwarunkowania i początki wykorzystywania energii słonecznej na świecie

Energetyka słoneczna stanowi gałąź przemysłu, która zajmuje się wykorzystaniem energii promieniowania słonecznego. Energia pozyskiwana ze Słońca, podobnie jak w przypadku energii wiatru czy wody, jest zaliczana do odnawialnych źródeł energii.

Słońce jest głównym źródłem energii docierającej do Ziemi. Słońce stanowi rozżarzoną kulę gazową o masie 1,989E30 kg, temperaturze powierzchni około $5800 \mathrm{~K}$ i średniej odległości od Ziemi 149,6 mln km (El-Sharkawi, 2005). Słońce składa się z 71\% (wagowych) wodoru i $27 \%$ helu. Gigantyczna energia emitowana przez Słońce powstaje w jego jądrze (Woolfson, 2000). W temperaturze około $15 \mathrm{mln}^{\circ} \mathrm{C}$ odbywają się reakcje termojądrowe, w których jądra wodoru przekształcają się w hel i wydziela się energia w postaci promieniowania i ciepła (Broggini, 2003). Naukowcy obliczyli, że w ciągu każdej sekundy $657 \mathrm{mln}$ ton wodoru przekształca się w głębi Słońca w $653 \mathrm{mln}$ ton helu. Różnica masy, $4 \mathrm{mln}$ ton na sekundę, zostaje zamieniona na energię.

Promieniowanie docierające do Ziemi możemy podzielić na:

- bezpośrednie - rozchodzi się w linii prostej od Słońca i ma największe znaczenie w wykorzystaniu energii słonecznej,

- odbite - promienie słoneczne odbijają się w zasadzie od wszystkich powierzchni, z wyjątkiem ciał czarnych, a najintensywniej od świeżego śniegu,

- rozproszone - jest to promieniowanie o długiej długości fali i odpowiada za widziany niebieski kolor nieba; udział promieniowania rozproszonego również zmienia się w ciągu roku i największe wartości osiągane są w miesiącach zimowych.

Słońce wypromieniowuje w przestrzeń kosmiczną w czasie jednej sekundy 3,8.1026 J energii (Phillips, 1995). Górna powierzchnia atmosfery ziemskiej otrzymuje rocznie około $1,5.1021 \mathrm{~J}$ energii słonecznej. $\mathrm{Z}$ tej energii 0,4 .1021 J zużywane jest na procesy parowania, opady, przepływy powierzchniowe wód, przemieszczanie się mas powietrza w atmosferze itp., pozostała część jest pochłaniana przez atmosferę, hydrosferę i biosferę Ziemi (Lawrence, 2013).

Moc emitowana przez Słońce nie jest rozmieszczona równomiernie na kuli ziemskiej. Najwięcej energii otrzymują obszary przy równiku, a najmniej - obszary okołobiegunowe. Sumaryczna energia, jaka dociera do powierzchni poziomej w ciągu całego roku, wynosi od $600 \mathrm{kWh} /\left(\mathrm{m}^{2} \times\right.$ rok) w krajach skandynawskich do ponad $2500 \mathrm{kWh} / \mathrm{m}^{2} / \mathrm{rok}$ w centralnej Afryce. W Polsce wynosi około $1100 \mathrm{kWh} /\left(\mathrm{m}^{2} \times\right.$ rok) (Zirker, 2002).

Energia Słońca była wykorzystywana od dawna w procesach rozniecania ognia, oświetlania, ogrzewania pomieszczeń czy suszenia produktów spożywczych.

Współcześnie energia pochodząca ze Słońca może być praktycznie wykorzystywana na kilka sposobów:

- kolektory słoneczne służące do wytwarzania ciepła,

- pompy ciepła służące do wytwarzania ciepła,

- termiczne elektrownie słoneczne,

- ogniwa fotowoltaiczne służące do produkcji energii elektrycznej (Tytko, 2017).

Wykorzystywanie energii Słońca posiada wiele zalet i jest szczególnie istotne z punktu widzenia środowiska naturalnego:

- nie emituje gazów cieplarnianych,

- ma niskie koszty eksploatacji,

- zapewnia korzyści finansowe, 
- zapewnia decentralizację,

- zapewnia równowagę elektroenergetyczną,

- w pełni wykorzystuje dostępną energię,

- nie powoduje żadnych zanieczyszczeń,

- nie pociąga za sobą produkcji odpadów (Jastrzębska, 2013).

Popularna obecnie fotowoltaika to system zeroemisyjny. Oznacza to, że w trakcie produkcji energii nie emituje szkodliwych związków i dwutlenku węgla, ani żadnych innych gazów cieplarnianych. Warto zwrócić uwagę na zwrot energetyczny instalacji, który określa, po jakim czasie energia wyprodukowana przez system fotowoltaiczny przekroczy energię potrzebną na produkcję podzespołów fotowoltaicznych. W tej technologii energia wykorzystana do produkcji podzespołów „Zwraca się” po 2-3 latach działania instalacji.

Dzięki wykorzystaniu technologii półprzewodnikowej, braku elementów ruchomych i prostocie systemu staje się on praktycznie bezobsługowy. Dodatkowym atutem są długie okresy gwarancji na podzespoły - np. dla paneli fotowoltaicznych do 25 lat.

Dzięki nowelizacji prawa energetycznego przyłączanie instalacji stało się bardzo łatwe, a wytwórca energii nie potrzebuje prowadzić działalności gospodarczej. Zwroty z inwestycji wynoszą około 10 lat dla osób prywatnych i 7 lat dla firm.

W przypadku mikroinstalacji energia elektryczna powstaje blisko konsumenta, dzięki czemu redukują się straty związane z przesyłem energii na duże odległości.

Produkcja energii elektrycznej z systemów fotowoltaicznych zachodzi w porze dnia, na którą przypada największe zapotrzebowanie na energię w kraju. Dzięki temu pokryte zostaje szczytowe zapotrzebowanie na prąd. Ułatwia to integrację fotowoltaiki z systemem energetycznym i odciąża elektrownie konwencjonalne.

W przeciwieństwie do systemów solarnych do ogrzewania wody panele fotowoltaiczne przetwarzają nie tylko promieniowanie bezpośrednie, ale także odbite i rozproszone w pochmurny dzień (Chochołowski, Krawiec, 2008).

Oprócz korzyści, wykorzystywanie energii promieniowania słonecznego może wiązać się z trudnościami, takimi jak:

- zmienność dobowa i sezonowa promieniowania słonecznego,

- mała gęstość dobowa strumienia energii promieniowania słonecznego, która nawet w rejonach równikowych wynosi zaledwie $300 \mathrm{~W} / \mathrm{m}^{2}$, zaś w Polsce nie przekracza 100 $\mathrm{W} / \mathrm{m}^{2}$, czyli $1000 \mathrm{kWh} / \mathrm{m}^{2}$ w skali roku,

- wysokie ceny budowy urządzeń, wynikające np. z wykorzystywanego w ogniwach fotowoltaicznych krzemu o wysokiej czystości, wytwarzanego w drogiej technologii próżniowej,

- trudności z magazynowaniem energii,

- ogniwa fotowoltaiczne budowane są z użyciem szkodliwych substancji,

- ustawione ogniwa zajmują dużą powierzchnię.

Początki zainteresowania wykorzystaniem Słońca do produkcji energii elektrycznej datują się na 1839 r., kiedy Aleksander Cezar Becquerel odkrył efekt fotowoltaiczny (Williams, 1960). Następnie w 1904 r. Albert Einstein opublikował dokument na temat efektu fotowoltaicznego. Natomiast w 1950 roku Laboratoria Bell wyprodukowały pierwsze ogniwo PV do celów kosmicznych. Od lat 70. XX w. fotowoltaika była wykorzystywana w celach gospodarczych. W 1999 r. moc baterii słonecznych zainstalowanych na całym świecie osiągnęła liczbę 1000 MW. 
Od początku XXI w. wykorzystywanie energii słonecznej rozwija się w tempie około 40\% rocznie. Od 2006 roku ogniwa o mocy ponad 1 GW były instalowane corocznie w takich krajach, jak: Niemcy, Włochy, Hiszpania, Szwajcaria, Austria, Francja. Globalne inwestycje w energię słoneczną w 2014 roku wyniosły 149,6 mld dolarów. W 2015 roku łączna moc zainstalowanych ogniw słonecznych wynosiła $230 \mathrm{GW}$ (wzrost o $50 \mathrm{GW}$ w stosunku do 2014 r.) i zaspokajały 1\% światowego zapotrzebowania na energię elektryczną.

W niektórych krajach energetyka słoneczna stanowi ważne źródło energii. Listę krajów o największej mocy ogniw fotowoltaicznych przedstawia tab. 1.

Tab. 1. Kraje o największej mocy ogniw fotowoltaicznych na świecie w MW

\begin{tabular}{|l|c|c|c|c|}
\hline \multicolumn{1}{|c|}{ Kraj } & $\mathbf{2 0 1 4}$ & $\mathbf{2 0 1 5}$ & $\mathbf{2 0 1 6}$ & $\begin{array}{c}\text { Udział na świecie } \\
\text { w 2016 }\end{array}$ \\
\hline Chiny & 28199 & 43480 & 78070 & $18,9 \%$ \\
\hline Niemcy & 38200 & 39700 & 42750 & $17,2 \%$ \\
\hline Japonia & 23300 & 35400 & 41275 & $15,4 \%$ \\
\hline USA & 18280 & 25600 & 40300 & $11,1 \%$ \\
\hline Włochy & 18460 & 18900 & 19279 & $8,2 \%$ \\
\hline Wielka Brytania & 5228 & 9070 & 11727 & $3,9 \%$ \\
\hline Francja & 5660 & 6557 & 7130 & $2,8 \%$ \\
\hline
\end{tabular}

Źródło: opracowanie własne na podstawie Statistical Review of World Energy (2017)

Analiza danych zamieszczonych w tabeli 1 wyraźnie wskazuje, że największy udział w światowym rynku ogniw fotowoltaicznych w 2016 r. miały Chiny, Niemcy i Japonia.

\section{Wykorzystywanie energetyki słonecznej w Polsce}

Wykorzystywanie odnawialnych źródeł energii w Polsce systematycznie wzrasta. W 2009 r. OZE produkowały 4,5\% całkowitej energii w Polsce. W 2016 r. OZE zaspokajało około 5,3\% zapotrzebowania na energię. Polska zobowiązała się, że do 2020 r. 15\% jej energii będzie pochodziło ze źródeł odnawialnych.

W Polsce coraz popularniejsze staje się wykorzystywanie energii słonecznej do ogrzewania budynków wielorodzinnych, budynków użyteczności publicznej i basenów. Panele słoneczne można spotkać na dachach szpitali, na przedszkolach, pływalniach. Można również zobaczyć wolno stojące układy fotowoltaiczne zasilające znaki drogowe (Krupa, Soliński, 2012).

Praktyczne wykorzystanie energii promieniowania słonecznego w Polsce, podobnie jak w innych krajach, wymaga oszacowania potencjalnych i rzeczywistych zasobów energii słonecznej w danym rejonie i parametryzacji warunków meteorologicznych dostosowanych do potrzeb technologii przetwarzania energii promieniowania słonecznego w inne formy energii - w energię elektryczną lub cieplną (Góralczyk, Tytko, 2016).

Polska, podobnie jak większość krajów europejskich, leży w obszarze klimatu umiarkowanego. Jej nasłonecznienie nie różni się zasadniczo od nasłonecznienia występującego w krajach Europy Środkowej na obszarach o zbliżonych szerokościach geograficznych. Nasłonecznienie w poszczególnych regionach Polski przedstawia rycina 1. 
Ryc. 1. Roczne sumy promieniowania słonecznego na powierzchni Polski

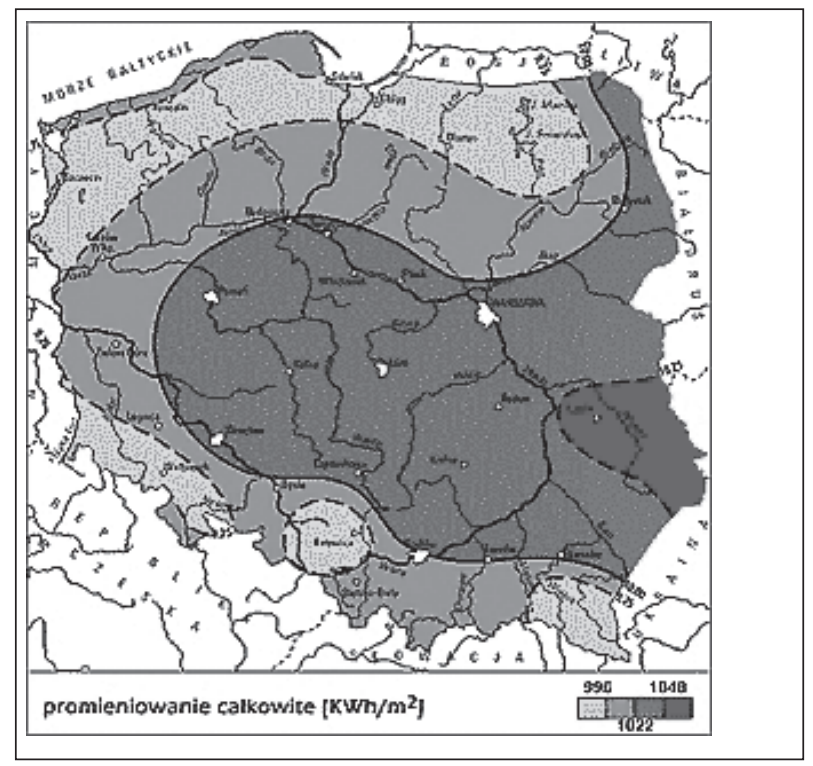

Źródło: Polska Agencja Zarządzania Energią

W Polsce największe roczne sumy promieniowania słonecznego występują w regionie lubelskim, natomiast najmniejsze - w województwie śląskim. Wpływa to w istotny sposób na opłacalność inwestycji solarnych.

$\mathrm{Z}$ punktu widzenia wykorzystania energii promieniowania słonecznego w kolektorach najistotniejszymi parametrami są roczne wartości nasłonecznienia - wyrażające ilość energii słonecznej padającej na jednostkę powierzchni płaszczyzny w określonym czasie. Roczna gęstość promieniowania słonecznego w Polsce na płaszczyznę poziomą waha się w granicach 950-1250 kWh/m², natomiast średnie usłonecznienie wynosi 1600 godzin na rok. W całej Polsce, od północy aż do południa, intensywność nasłonecznienia wystarczy do pokrycia całkowitych potrzeb energetycznych w 60\%, a latem nawet w $100 \%$.

Biorąc pod uwagę roczne sumy promieniowania całkowitego padającego na powierzchnię poziomą, na obszarze Polski wyodrębnić można cztery podstawowe regiony:

1. pas nadmorski, ograniczony izolinią $950 \mathrm{kWh} / \mathrm{m}^{2}$ rok, z Kołobrzegiem jako miejscem charakterystycznym, w którym znajduje się stacja aksonometryczna,

2. wschodnia część Polski, ograniczona izolinią $950 \mathrm{kWh} / \mathrm{m}^{2}$ rok, reprezentowana przez Zamość,

3. pozostała część Polski od południa ograniczona izolinią $900 \mathrm{kWh} / \mathrm{m}^{2}$ rok, reprezentowana przez stację Brwinów koło Warszawy,

4. południowa część Polski ograniczona od północy izolinią $900 \mathrm{kWh} / \mathrm{m}^{2}$ rok, ze stacją Zakopane.

Warunki meteorologiczne w Polsce charakteryzują się nierównomiernym rozkładem promieniowania słonecznego w cyklu rocznym: 80\% całkowitej rocznej sumy nasłonecznienia przypada na sześć miesięcy sezonu wiosenno-letniego (od początku kwietnia do końca września). Dodatkowo czas operacji słonecznej w zimie skraca się do 8 godzin dziennie, a w lecie w miesiącach najbardziej słonecznych wydłuża się do 16 godzin. 
Na praktyczne wykorzystanie energii słonecznej w celach grzewczych wpływają również takie czynniki, jak:

- przejrzystość powietrza,

- kąt padania promieni słonecznych.

Zmniejszenie przezroczystości atmosfery ziemskiej może też być wywołane przez zawieszone w niej liczne cząsteczki pyłu, dymu itp. Cząstki suche o średnicy większej od długości fali świetlnej tworzą mlecznobiałe zmętnienie atmosfery. Chmury, stanowiące zbiór kropelek wody lub kryształów powstających w efekcie kondensacji (krystalizacji) zawartej w powietrzu pary wodnej, ograniczają i rozpraszają promieniowanie słoneczne, dochodzące do ziemi w postaci rozproszonego, a nie bezpośredniego promieniowania.

Kąt nachylenia powinien być optymalny. Największe nasłonecznienie otrzymuje płaszczyzna ustawiona w stosunku do pozornego ruchu Słońca tak, aby promienie padały na nią prostopadle. Dla obszaru Polski położonego w północnych szerokościach geograficz-

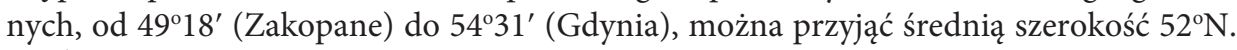

Światowy potencjał produkcji energii elektrycznej i cieplnej przekracza 440 tys. TWh na rok. Według ekspertyzy Europejskiego Centrum Energii Odnawialnej (ECEO) rzeczywisty potencjał techniczny odnawialnych źródeł energii występujących w Polsce wynosi około $2514 \mathrm{PJ}$ /rok (z czego $1340 \mathrm{PJ} /$ rok, czyli 53\%, przypada na promieniowanie słoneczne). Stanowi to prawie $60 \%$ zapotrzebowania na energię pierwotną.

Pierwsza farma fotowoltaiczna powstała w Polsce w 2011 r. w gminie Wierzchosławice w regionie małopolskim. Na koniec 2014 roku łącznie zainstalowanych i użytkowanych było około 1,7 mln $\mathrm{m}^{2}$ kolektorów słonecznych, co odpowiada 1,2 GWt mocy cieplnej. Całkowita zainstalowana moc kolektorów słonecznych powoduje, że są one drugim, po ciepłowniach na biomasę, odnawialnym źródłem wytwarzania „zielonego ciepła” w Polsce. W 2014 roku Polska zajęła czwarte miejsce w sprzedaży instalacji słonecznych wśród krajów europejskich.

Całkowita moc podłączonych do sieci elektrowni fotowoltaicznych (ang. skrót PV) w Polsce wynosiła na koniec 2012 roku około 1,29 MWp. Według Instytutu Energetyki Odnawialnej całkowita moc ogniw fotowoltaicznych w Polsce we wrześniu 2014 roku wynosiła około 6,6 MWp. Według Urzędu Regulacji Energii (URE) w połowie 2016 roku moc ogniw PV zainstalowanych w Polsce wynosiła 91,82 MWp.

W grudniu 2016 r. w Polsce działały 473 instalacje fotowoltaiczne posiadające koncesję Urzędu Regulacji Energetyki, o łącznej mocy 99,1 MW, oraz ponad 17 tys. mikroinstalacji przyłączonych do sieci na zgłoszenie, o łącznej mocy 93,72 MW. Razem daje to ponad 17,5 tys. systemów PV o całkowitej mocy nominalnej 192,82 MW.

Liderem wśród województw, pod względem zainstalowanej mocy w koncesjonowanych elektrowniach PV, jest województwo lubelskie, w którym na koniec 2016 r. było 55 elektrowni fotowoltaicznych o łącznej mocy 30,8 MW. Ten region w Polsce posiada najdogodniejsze warunki do wykorzystywania energii słonecznej.

\section{Energetyka słoneczna jako czynnik rozwoju regionów i gmin w Polsce}

Energetyka słoneczna w Polsce staje się coraz bardziej popularna. Z roku na rok rośnie liczba nowych instalacji solarnych, w tym również farm fotowoltaicznych. W pierwszym przypadku indywidualni użytkownicy uzyskują przede wszystkim korzyści z tytułu ograniczenia kosztów ogrzewania wody. W przypadku fotowoltaiki dochodzą również zyski ze sprzedaży energii (Więcka, Wiśniewski, Kurowski, Gryciuk, 2008). 
Największą szansę na korzystanie z dobrodziejstw energetyki słonecznej mają te regiony Polski, które charakteryzują się największym rocznym nasłonecznieniem. Z tego powodu rozmieszczenie farm fotowoltaicznych w Polsce nie jest równomierne. Lokalizację farm fotowoltaicznych w poszczególnych regionach Polski przedstawia tabela 2.

Tab. 2. Liczba instalacji fotowoltaicznych i ich moc w poszczególnych regionach Polski w 2016 roku

\begin{tabular}{|l|c|c|}
\hline \multicolumn{1}{|c|}{ Region } & Liczba instalacji & Moc w MW \\
\hline Dolnośląski & 18 & 2,6 \\
\hline Kujawsko-Pomorski & 14 & 7,1 \\
\hline Lubelski & 55 & 30,8 \\
\hline Lubuski & 17 & 3,4 \\
\hline Łódzki & 17 & 2,2 \\
\hline Małopolski & 44 & 9,0 \\
\hline Mazowiecki & 26 & 1,7 \\
\hline Opolski & 12 & 0,9 \\
\hline Podkarpacki & 30 & 4,1 \\
\hline Podlaski & 22 & 8,6 \\
\hline Pomorski & 12 & 2,3 \\
\hline Śląski & 106 & 6,9 \\
\hline Świętokrzyski & 16 & 0,5 \\
\hline Wielkopolski & 40 & 6,5 \\
\hline Warmińsko-Mazurski & 33 & 8,8 \\
\hline Zachodniopomorski & 11 & 3,6 \\
\hline
\end{tabular}

Źródło: opracowanie własne na podstawie danych Polskiego Towarzystwa Fotowoltaiki

Analiza danych zawartych w tabeli 2 wyraźnie wskazuje, że w Polsce regionem o największej zainstalowanej mocy farm fotowoltaicznych jest region lubelski, co wynika z jego najlepszych warunków w zakresie nasłonecznienia. Świadczy to o tym, że omawiany region prawidłowo wykorzystuje swoje naturalne atuty. Województwo warmińsko-mazurskie, którego nasłonecznienie roczne należy do najniższych w kraju, zajmuje drugą lokatę pod względem zainstalowanej mocy ogniw fotowoltaicznych. Region śląski, pomimo niskiego nasłonecznienia, może się pochwalić największą liczbą instalacji fotowoltaicznych.

Natomiast zaskakującym jest fakt, że takie regiony, jak świętokrzyski, mazowiecki czy łódzki, które mają wysokie wskaźniki nasłonecznienia w Polsce, nie zainwestowały do tej pory $\mathrm{w}$ fotowoltaikę na wysokim poziomie.

W grudniu 2016 r. 25 elektrowni słonecznych w Polsce miało moc co najmniej $1 \mathrm{MW}$. W tym samym okresie łączna moc systemów fotowoltaicznych w Polsce wynosiła blisko 193 MW, a składało się na nią 17,5 tys. instalacji. Zestawienie największych polskich farm fotowoltaicznych przedstawia rycina 2.

Farmy fotowoltaiczne w Polsce są instalowane głównie na obszarach wiejskich, peryferyjnych, oddalonych od tradycyjnych źródeł energii (np. elektrociepłowni węglowych). Korzyści dla regionów i społeczności lokalnych wynikające z funkcjonowania farm fotowoltaicznych to przede wszystkim korzyści finansowe, ekologiczne, a także ożywienie gospodarcze lokalnego rynku i nowe miejsca pracy. 
Ryc. 2. Największe farmy fotowoltaiczne w Polsce w 2016 r.

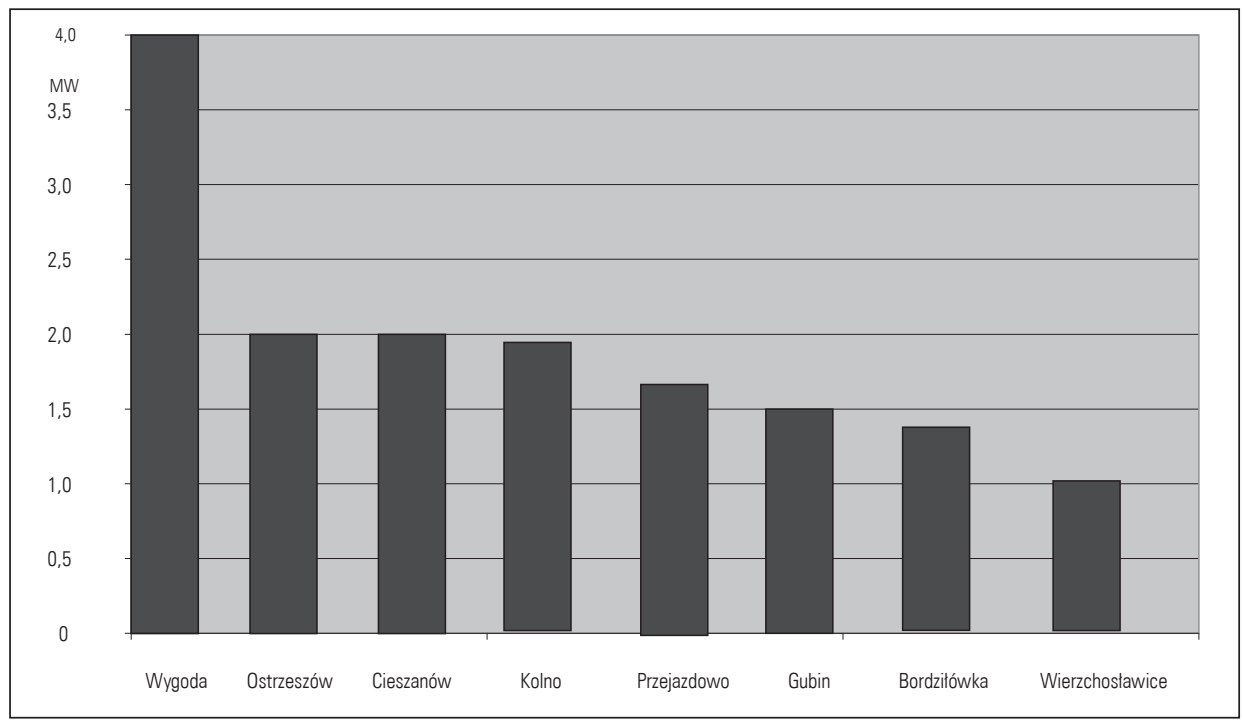

Źródło: opracowanie własne na podstawie Moc elektrowni fotowoltaicznych w Polsce przekroczyła 190 MW (2017)

Działająca od 2011 r., jako pierwsza w Polsce, farma fotowoltaiczna w gminie Wierzchosławice w Małopolsce była pionierem wykorzystania energii słonecznej w Polsce (Wasa, 2011). Powstała przy wsparciu unijnym w wysokości 50\% wartości inwestycji, przy założeniu, że koszty jej budowy zwrócą sie w ciągu siedmiu lat. W ciągu dwóch lat zarobiła na handlu energią 900 tys. zł. W pierwszym roku instalacja wyprodukowała ponad 1000 MWh energii elektrycznej, co było wynikiem lepszym od prognozowanego. Oprócz dochodów ze sprzedaży energii gmina będzie zarabiała na sprzedaży zielonych certyfikatów. Ponadto planuje się zwiększyć moc ogniw z obecnego poziomu $1 \mathrm{MW}$ do 10 MW. Dzięki temu szacowane przychody gminy wzrosną do poziomu 4-8 mln zł na rok. Dzięki fotowoltaice poprawiła sie sytuacja dotycząca bezrobocia w gminie oraz wzrosły wydatki budżetu gminy (ryc. 3).

Dane zawarte na rycinie 3 wskazują na spadek odsetka osób bezrobotnych w badanym okresie w gminie Wierzchosławice oraz na wzrost wydatków budżetu gminy w obszarach kultury, gospodarki komunalnej i ochrony środowiska, a w szczególności rolnictwa.

Pozytywne doświadczenia Wierzchosławic motywują do kolejnych inwestycji solarnych w Małopolsce, ale także poza nią. Następne instalacje mają powstać w niedalekich miejscowościach Jadowniki i Wał Ruda.

Największa farma fotowoltaiczna w Polsce pracuje od 2015 r. w miejscowości Wygoda w gminie Czernikowo koło Torunia. Inwestycja wybudowana przez grupę Energa, o mocy prawie $4 \mathrm{MW}$, produkuje rocznie 3,5 GWh energii elektrycznej. Powyższa moc wystarcza na pokrycie zapotrzebowania na energię dla około 1600 gospodarstw domowych i pozwoli na uniknięcie emisji $\mathrm{CO}_{2} \mathrm{w}$ ilości 3 tys. ton, które wytworzono by w przypadku produkcji podobnej ilości energii w elektrowni węglowej.

Inny przykład udanej inwestycji stanowi instalacja fotowoltaiczna w gminie Ostrzeszów w województwie wielkopolskim. Całkowity koszt inwestycji wyniósł 17,5 mln zł, 
Ryc. 3. Udział bezrobotnych zarejestrowanych $\mathrm{w}$ liczbie ludności $\mathrm{w}$ wieku produkcyjnych $\mathrm{w} \%$ oraz wydatki budżetu gminy w wybranych obszarach w latach 2013-2015 w gminie Wierzchosławice w \%

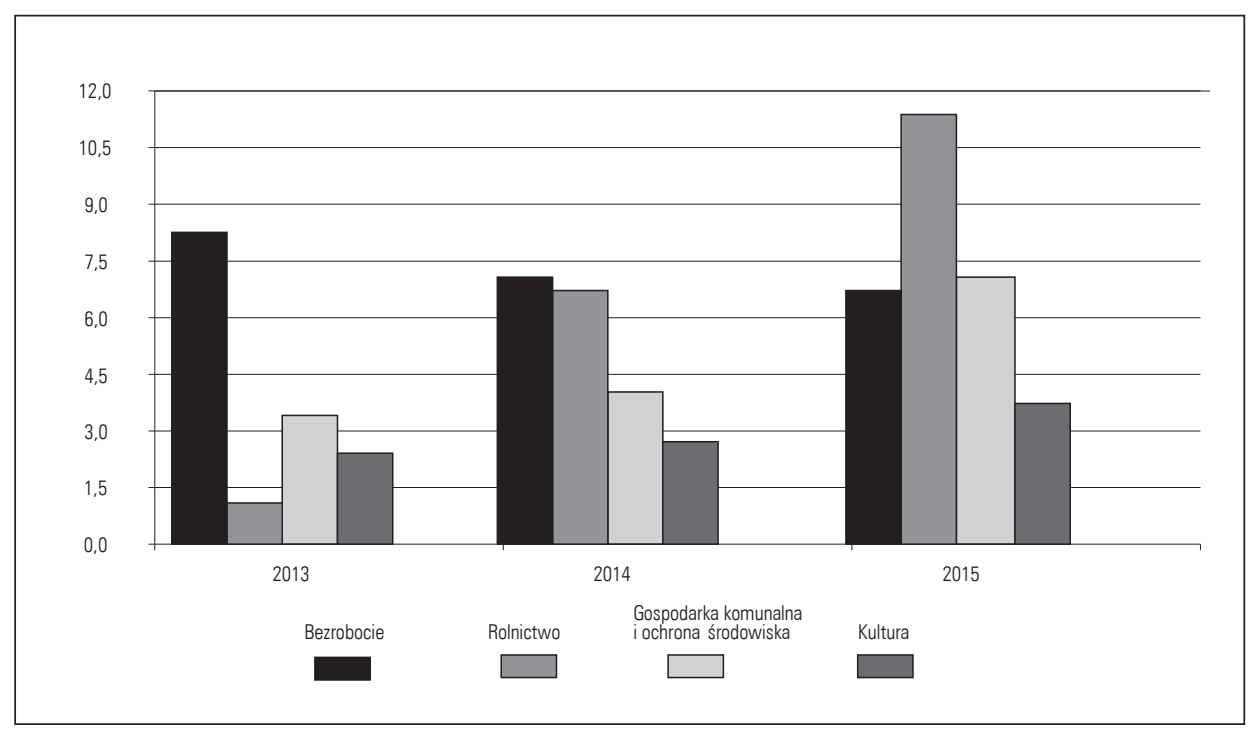

Źródło: opracowanie własne na podstawie: Statystyczne vademecum samorządowca (2017)

przy unijnej dotacji na poziomie $8,5 \mathrm{mln}$ zł. Farma fotowoltaiczna w Ostrzeszowie ma moc 2 MW i powstała na powierzchni 3,33 ha. Powierzchnia modułów PV wynosi $11155 \mathrm{~m}^{2}$. Korzyści dla lokalnej społeczności to roczny uzysk energii 1,70-1,90 TWh, czyli 19440 GJ/rok energii pierwotnej. Przekłada się to na redukcję około 1910 ton (Mg) emisji $\mathrm{CO}_{2}$ rocznie. Dzięki inwestycji zaoszczędzone zostanie $19440 \mathrm{GJ} /$ rok energii pierwotnej (Farma fotowoltaiczna Ostrzeszów, 2017). Korzyści finansowe dla budżetu niektórych gmin $\mathrm{z}$ instalacjami fotowoltaicznymi przedstawia tab. 3 .

Tab. 3. Dochody ogółem na 1 mieszkańca budżetu niektórych gmin, które uruchomiły farmy fotowoltanicznew latach 2013-2015 (w zł)

\begin{tabular}{|l|c|c|c|c|}
\hline \multicolumn{1}{|c|}{ Gmina } & $\begin{array}{c}\text { Rok } \\
\text { uruchomienia } \\
\text { instalacji }\end{array}$ & $\mathbf{2 0 1 3}$ & $\mathbf{2 0 1 4}$ & $\mathbf{2 0 1 5}$ \\
\hline Gubin & 2014 & 2936 & 3054 & 3142 \\
\hline Kolno & 2014 & 2634 & 2763 & 3095 \\
\hline $\begin{array}{l}\text { Przejazdowo/Pruszcz } \\
\text { Gdański }\end{array}$ & 2014 & 3998 & 3525 & 3668 \\
\hline Bordziłówka/Rossosz & 2014 & 3023 & 4838 & 5236 \\
\hline Wierzchosławice & 2011 & 2281 & 2433 & 2700 \\
\hline
\end{tabular}

Źródło: opracowanie własne na podstawie danych GUS

Dane zawarte w tabeli 3 wyraźnie pokazują pozytywne tendencje w uzyskiwanych dochodach budżetowych gmin, które postawiły na energetykę słoneczną. Największe korzyści finansowe w podanym zestawieniu uzyskała gmina Rossosz. W latach 2013-2015 jej budżet wzrósł o prawie $60 \%$. 
Przytoczone dane wskazują, że opłaca się inwestować w energetykę słoneczną. Dzięki uzyskanym w sposób ekologiczny środkom finansowym społeczności lokalne zamieszkałe w poszczególnych regionach mogą pozwolić sobie na większe wydatki i inwestycje społeczne.

\section{Zakończenie}

Regiony i gminy, które postawiły na rozwój energetyki słonecznej, należy bez wątpienia uznać za przedsiębiorcze. Biorąc pod uwagę interes społeczny, gospodarczy czy też środowiska naturalnego, inwestycje w zieloną energetykę słoneczną stanowią rozsądny kompromis.

Energetyka słoneczna może z pewnością stanowić ważny czynnik rozwoju regionów i gmin zwłaszcza pod względem finansowym, zarówno na świecie, jak i w Polsce.

W Polsce rozwój fotowoltaiki może być szczególnie istotny w przypadku regionów biedniejszych (np. ściany wschodniej). Województwo lubelskie, które ma najkorzystniejsze warunki pod tym względem w Polsce, staje przed największymi możliwościami zarabiania na ekologicznej energii oraz kreowania nowych miejsc pracy. Za przykładem lubelskiego podążają również inne, słabiej rozwinięte regiony, a w szczególności warmińsko-mazurski i podlaski.

Nieustanny rozwój tego rodzaju energetyki odnawialnej w Polsce i budowa kolejnych farm fotowoltaicznych stanowi dowód, że fotowoltaika w Polsce trafiła na podatny grunt. W przyszłości należy się w dalszym ciągu spodziewać wzrostu mocy instalacji słonecznych.

\section{Literatura}

References

Broggini, C. (2003). Nuclear Processes at Solar Energy. Pozyskano z: https://arxiv.org/abs/astro-ph/0308537 Chochołowski, A., Krawiec, F. (2008). Zarządzanie w energetyce. Warszawa: Difin.

El-Sharkawi, M.A. (red.) (2005). Electric energy. Boca Raton: CRC Press.

Farma fotowoltaiczna Ostrzeszów (2017, 2 sierpnia). Pozyskano z: http://inwestycjeenergetyczne.itc. pw.edu.pl/inwestycja/farma-fotowoltaiczna-ostrzeszow/

Farmy fotowoltaiczne w Polsce (2017, 12 czerwca). Pozyskano z: http://info.wyborcza.biz/szukaj/gospodarka/farmy+fotowoltaiczne+w+polsce

Góralczyk, I., Tytko, R. (2016). Fotowoltaika. Kraków: Eco Investment.

Jastrzębska, G. (2013). Ogniwa słoneczne. Budowa, technologia i zastosowanie. Warszawa: Wydawnictwo Komunikacji i Łączności.

Krupa, J., Soliński, T. (red.) (2012). Ochrona środowiska w aspekcie zrównoważonego rozwoju społeczno-gospodarczego Pogórza Dynowskiego. Dynów: Związek Gmin Turystycznych Pogórza Dynowskiego.

Lawrence, J.E. (2013). Słoneczny kataklizm. Białystok: Illuminatio.

Małopolski Ośrodek Doradztwa Rolniczego z siedzibą w Karniowicach (2017, 23 sierpnia). Pozyskano z: http://www.modr.pl/sub.php?mb=5\&t=271

Mapa instalacji OZE (2017, 3 maja). Gram w zielone. Portal zielonej energii. Pozyskano z: http://gramwzielone.pl/mapa-instalacji-oze/elektrownia-fotowoltaiczna

Moc elektrowni fotowoltaicznych w Polsce przekroczyła 190 MW (2017, 10 września). Gram w zielone. Portal zielonej energii. Pozyskano z: http://gramwzielone.pl/energia-sloneczna/25391/moc-elektrowni-fotowoltaicznych-w-polsce-przekroczyla-190-mw 
Największa farma fotowoltaiczna w Polsce uruchomiona pod Toruniem (2017, 3 sierpnia). Gram w zielone. Portal zielonej energii. Pozyskano z: http://gramwzielone.pl/energia-sloneczna/18778/ najwieksza-farma-fotowoltaiczna-w-polsce-uruchomiona-pod-toruniem

Phillips, K.J.H. (1995). Guide to the Sun. Cambridge University Press.

Ryan, S.G., Norton, A.J. (2010). Stellar Evolution and Nucleosynthesis. Cambridge: Cambridge University Press.

Statistical Review of World Energy (2017, 10 września). Pozyskano z: https://www.bp.com/en/global/ corporate/energy-economics/statistical-review-of-world-energy.html

Statystyczne vademecum samorządowca (2017, 10 września). Pozyskano z: http://krakow.stat.gov.pl/vademecum/vademecum_malopolskie/portrety_gmin/powiat_tarnowski/wierzchoslawice.pdf

Tytko, R. (2017). Urządzenia i systemy energetyki odnawialnej. Kraków: Eco Investment.

Wasa, M. (2011). Pierwsza w Polsce farma PV o mocy 1 MW. Magazyn Fotowoltaika, 3.

Więcka, A., Wiśniewski, G., Kurowski, K., Gryciuk, M., (2008). Kolektory słoneczne. Energia słoneczna w mieszkalnictwie, hotelarstwie i drobnym przemyśle. Warszawa: Medium sp. z o.o. Sk-A Grupa.

Williams, R. (1960). Becquerel Photovoltaic Effect in Binary Compounds. The Journal of Chemical Physics, 32(5).

Woolfson, M. (2000). The origin and evolution of the solar system. Astronomy \& Geophysics, 41(1).

Zalety fotowoltaiki (2017, 4 lipca). Czysty zysk. Twój zysk z energii słońca. Pozyskano z: http://czysty-zysk.pl/zalety-fotowoltaiki

Ziętal, N. (2017, 23 kwietnia). W Cieszanowie mają energię elektryczną ze słońca. Nowiny24. Pozyskano z:

http://www.nowiny24.pl/strefa-biznesu/pieniadze/a/w-cieszanowie-maja-energie-elektrycznaze-slonca,10183324/

Zirker, J.B. (2002). Journey from the Center of the Sun. Princeton: Princeton University Press.

Krzysztof Sala, dr, adiunkt. Absolwent Międzynarodowych Stosunków Gospodarczych (specjalność: studia europejskie) na Uniwersytecie Ekonomicznym w Krakowie (studia magisterskie) zakończonych dyplomem na podstawie pracy Realizacja polityki ekorozwoju w krajach skandynawskich, podyplomowych studiów w zakresie zarządzania jakością i ochroną środowiska w Wyższej Szkole Zarządzania i Bankowości w Krakowie oraz Kolegium Zarządzania i Finansów Szkoły Głównej Handlowej w Warszawie, zakończone uzyskaniem tytułu doktora nauk ekonomicznych na podstawie rozprawy Nowe rodzaje turystyki jako przejaw postmodernizmu zachowań konsumenckich $w$ Polsce. Do głównych obszarów zainteresowań zalicza politykę gospodarczą i turystyczną Polski i Unii Europejskiej, przedsiębiorczość w sektorze małych i średnich firm oraz zarządzanie strategiczne.

Krzysztof Sala, PhD, research assistant. A graduate of International Economic Relations (specialisation European Studies) at the Cracow University of Economics (MA degree) completed diploma on the basis of the work Implementation of the policy of sustainable development in the Nordic countries, post-graduate studies in the field of quality management and environmental protection School of Management and Banking in Krakow and the College of Management and Finance School of Economics in Warsaw, leading to a doctoral degree in economic sciences for the thesis New types of tourism as a manifestation of postmodern consumer behavior in Poland. The main areas of interest include economic and tourism policy in Poland and in the European Union, entrepreneurship in small and medium-sized businesses, and strategic management.

\section{Adres/Address:}

Uniwersytet Pedagogiczny im. Komisji Edukacji Narodowej w Krakowie

Wydział Politologii

Instytut Prawa, Administracji i Ekonomii

Katedra Ekonomii i Polityki Gospodarczej

ul. Podchorążych 2

30-084 Kraków, Polska

e-mail: krzysztofsal@onet.pl 